Article

\title{
Anaerobic Degradation of Bicyclic Monoterpenes in Castellaniella defragrans
}

\author{
Edinson Puentes-Cala ${ }^{1}$, Manuel Liebeke ${ }^{2}$ (D), Stephanie Markert ${ }^{3}$ and Jens Harder ${ }^{1, *}$ \\ 1 Department of Microbiology, Max Planck Institute for Marine Microbiology, Celsiusstr. 1, 28359 Bremen, \\ Germany; epuentes@mpi-bremen.de \\ 2 Department of Symbiosis, Max Planck Institute for Marine Microbiology, Celsiusstr. 1, 28359 Bremen, \\ Germany; mliebeke@mpi-bremen.de \\ 3 Pharmaceutical Biotechnology, University Greifswald, Felix-Hausdorff-Straße, 17489 Greifswald, Germany; \\ stephanie.markert@uni-greifswald.de \\ * Correspondence: jharder@mpi-bremen.de; Tel.: +49-421-2028-750
}

Received: 23 January 2018; Accepted: 2 February 2018; Published: 7 February 2018

\begin{abstract}
The microbial degradation pathways of bicyclic monoterpenes contain unknown enzymes for carbon-carbon cleavages. Such enzymes may also be present in the betaproteobacterium Castellaniella defragrans, a model organism to study the anaerobic monoterpene degradation. In this study, a deletion mutant strain missing the first enzyme of the monocyclic monoterpene pathway transformed cometabolically the bicyclics sabinene, 3-carene and $\alpha$-pinene into several monocyclic monoterpenes and traces of cyclic monoterpene alcohols. Proteomes of cells grown on bicyclic monoterpenes resembled the proteomes of cells grown on monocyclic monoterpenes. Many transposon mutants unable to grow on bicyclic monoterpenes contained inactivated genes of the monocyclic monoterpene pathway. These observations suggest that the monocyclic degradation pathway is used to metabolize bicyclic monoterpenes. The initial step in the degradation is a decyclization (ring-opening) reaction yielding monocyclic monoterpenes, which can be considered as a reverse reaction of the olefin cyclization of polyenes.
\end{abstract}

Keywords: monoterpene; anaerobic metabolism; ring-opening reactions; carbon-carbon lyase; isoprenoid degradation

\section{Introduction}

Monoterpenes are a diverse family of biogenic (C10) hydrocarbons. They are synthesized by the condensation of two activated isoprene (C5) units [1,2], primarily as secondary metabolites in higher plants. In addition, some bacteria, fungi, algae and animals are minor monoterpene producers [3]. Global estimates for monoterpene emissions into the atmosphere range from 95 to $157 \mathrm{Tg} \mathrm{C} \mathrm{a}{ }^{-1}$, a considerable contribution to the total biogenic organic volatiles (760-1000 $\mathrm{Tg} \mathrm{C}^{-1}$ ) [4-7]. Monoterpenes contained in foliage are transported into soils, sediments and aquatic habitats, where they become growth substrates for microorganisms [8,9]. Most studies on monoterpene biodegradation since the first report in 1960 were focused on aerobic microorganisms [10-12]. The anaerobic degradation of these biogenic hydrocarbons was discovered in the mid-1990s in denitrifying strains [13], later described as Castellaniella (ex Alcaligenes) defragrans, Thauera linaloolentis and Thauera terpenica [14-16].

C. defragrans metabolizes more than a dozen structurally diverse monoterpenes to carbon dioxide [15], while most studied aerobic bacteria metabolize one or two closely related substrates [17]. For this reason, over the years, $C$. defragrans (particularly strain 65Phen) has become a model organism to study the anaerobic mineralization of monoterpenes. Several enzymatic steps of the degradation of acyclic and monocyclic monoterpenes have been characterized [18-21]. The hydration of $\beta$-myrcene 
to (S)-linalool, an oxygen-independent reaction catalyzed by the linalool dehydratase/isomerase, has raised interest for its industrial potential in the production of alkenes [18,22,23]. Another novelty is the anaerobic hydroxylation of limonene to perillyl alcohol, the first step in the oxidation of monocyclic monoterpenes $[19,20]$. A $70 \mathrm{~kb}$ genetic island in C. defragrans' genome seems to contain all genes necessary for the biotransformation of several monoterpenes including myrcene, linalool, geraniol, $\alpha$-phellandrene, limonene and pinene to central metabolites, e.g., of the citrate cycle $[19,21]$.

In contrast to acyclic and monocyclic monoterpenes, the enzymology of bicyclic monoterpene degradation in $C$. defragrans has not been investigated. Traces of monoterpenes were detected during growth on bicycles in the past, but a systematic study has not yet been conducted. Here, we studied the transformation of the bicyclic monoterpenes $\alpha$-pinene, sabinene and 3-carene, using several experimental approaches including the metabolite accumulation in mutants with a defect in the degradation pathway for monocyclic monoterpenes.

\section{Results}

\subsection{Metabolite Formation in Cultures}

In order to identify possible intermediates in the metabolism of the bicyclic monoterpenes, cultures of $C$. defragrans strains 65Phen (wild-type, rifampicin-resistant) and 65Phen $\triangle \operatorname{ctm} A B$ were grown in liquid artificial freshwater (AFW) medium with $20 \mathrm{mM}$ acetate and $3 \mathrm{mM}$ of either sabinene, 3 -carene or $\alpha$-pinene as carbon sources and $10 \mathrm{mM}$ nitrate as electron acceptor. Under these conditions, the limitation of nitrate may allow the accumulation of metabolites. Cultures without inoculum or with acetate as substrate served as control experiments. Cultures were harvested in early stationary phase, and hydrophobic substances were extracted and analyzed by gas chromatography with flame ionization detection (GC-FID) for quantification and with mass spectrum detection (GC-MS) for identification. Bicyclic monoterpenes were consumed by both strains, wild-type and $\triangle c t m A B$ (Table 1). Sabinene concentrations were reduced to half, while only a small portion of 3-carene or $\alpha$-pinene was consumed.

Table 1. Recovery of bicyclic monoterpenes from cultures of $C$. defragrans wild-type and $\triangle c t m A B$.

\begin{tabular}{ccc}
\hline \multirow{2}{*}{ Monoterpene Co-Substrate } & \multicolumn{2}{c}{ Monoterpene $(\mathbf{m M}),($ Monoterpene Consumed (\%)) } \\
\cline { 2 - 3 } & Wild-Type & \multicolumn{1}{c}{$\boldsymbol{\Delta c t m A B}$} \\
\hline sabinene & $1.6 \pm 0.6(47 \%)$ & $1.44 \pm 0.11(52 \%)$ \\
3-carene & $2.65 \pm 0.15(12 \%)$ & $2.68 \pm 0.02(11 \%)$ \\
$\alpha$-pinene & $2.95 \pm 0.03(2 \%)$ & $2.69 \pm 0.06(10 \%)$ \\
\hline
\end{tabular}

The decrease of bicyclic monoterpenes coincided with the formation of monocyclic monoterpenes and monoterpene alcohols in the cultures (Figure 1). These compounds were identified by retention time comparison with authentic standards and GC-MS analysis. Although both strains accumulated the same metabolites, their concentrations in wild-type cultures were considerably lower (in no case higher than $115 \mu \mathrm{M}$ ) than in cultures of the deletion mutant. The co-metabolism of acetate and sabinene in $\triangle c t m A B$ cultures led to the accumulation of the monoterpenes $\gamma$-terpinene $(368 \pm 35 \mu \mathrm{M})$ and $\alpha$-terpinene $(57 \pm 7 \mu \mathrm{M})$, and of the monoterpene alcohol terpinen-4-ol $(78 \pm 11 \mu \mathrm{M})$ (Figure $1 \mathrm{~A})$. Cultures consuming 3-carene accumulated $37 \pm 8 \mu \mathrm{M}$ of limonene and $23 \pm 14 \mu \mathrm{M}$ of $\alpha$-terpineol (Figure 1B). Coinciding with the disappearance of $\alpha$-pinene, $227 \pm 39 \mu \mathrm{M}$ of $\alpha$-terpinene, $32 \pm 10 \mu \mathrm{M}$ of limonene and $18 \pm 9 \mu \mathrm{M}$ of $\alpha$-terpineol were detected in $\triangle c t m A B$ cultures (Figure 1C). 
A

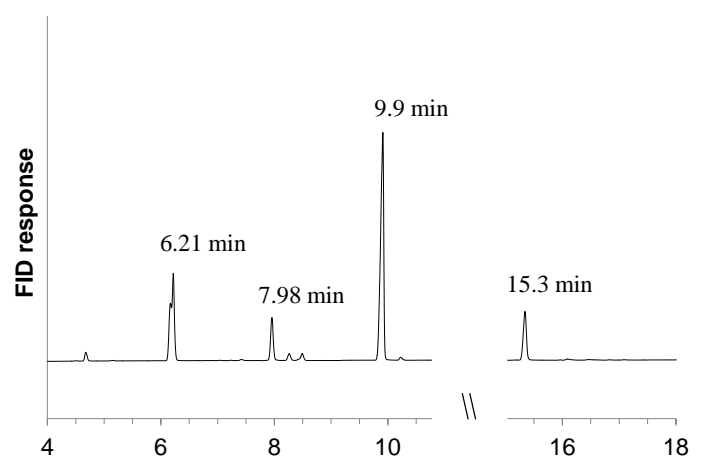

C

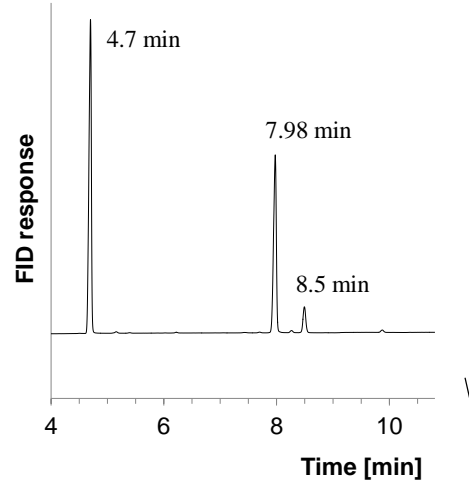

B

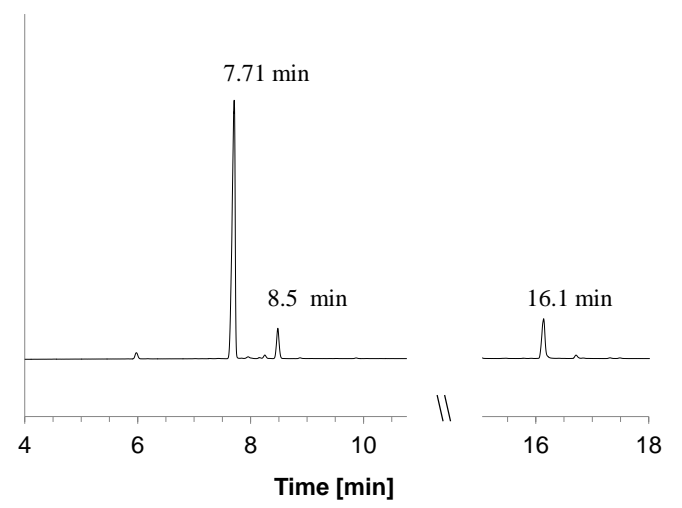

D

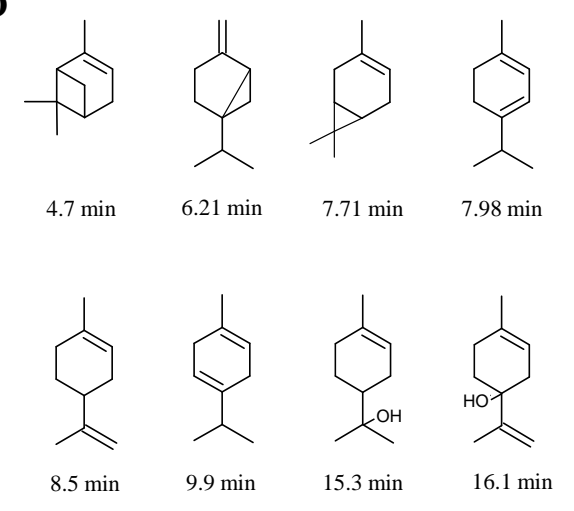

Figure 1. Metabolites formed in cultures of $C$. defragrans 65Phen $\triangle c t m A B$ grown on acetate in co-metabolism with sabinene (A), 3-carene (B) and $\alpha$-pinene (C). Monoterpenes were identified by retention time and mass spectrum. The retention times of monoterpenes (D) are: $\alpha$-pinene $(4.7 \mathrm{~min})$, sabinene $(6.21 \mathrm{~min}), 3$-carene $(7.71 \mathrm{~min}), \alpha$-terpinene $(7.98 \mathrm{~min})$, limonene $(8.5 \mathrm{~min}), \gamma$-terpinene (9.9 $\mathrm{min})$, terpinen-4-ol (15.3 $\mathrm{min})$ and $\alpha$-terpineol (16.1 $\mathrm{min})$.

\subsection{Metabolite Formation in Cell Lysates}

The in vitro biotransformation of bicyclic monoterpenes was assayed in cell lysates of $C$. defragrans 65Phen grown on $\alpha$-pinene. Several monocyclic products in the presence of each of the three bicycles as detected in hexane extracts by GC-FID (Figure 2). The main product of $\alpha$-pinene isomerization was terpinolene. The formation of this product was slightly stimulated by the addition of $\mathrm{Mg}^{2+}, \mathrm{Mn}^{2+}$ and ATP, from 2066 to $2334 \mathrm{fkat} \mathrm{mg}^{-1}$. After removal of endogenous low-molecular weight compounds by dialysis of the cell lysate, terpinolene formation decreased and, in addition, a limonene formation appeared. The apparent enzyme activity for terpinolene synthesis increased from 957 to $2508 \mathrm{fkat} \mathrm{mg}^{-1}$ and for limonene from 110 to $196 \mathrm{fkat} \mathrm{mg}^{-1}$ after addition of the cofactors. EDTA counteracted this stimulation suggesting an essential role of the divalent ions (Figure 2B). Separate assays showed that $\mathrm{Ca}^{2+}$ is also a suitable enzyme cofactor (data not shown). The isomerization of sabinene and 3 -carene was observed in crude and dialyzed cell lysates and also stimulated by the cofactor mixture. Incubations with sabinene yielded $\gamma$-terpinene as main product (3863 fkat $\mathrm{mg}^{-1}$ ) followed by $\alpha$-terpinene (702 fkat mg ${ }^{-1}$ ) and terpinolene (445 fkat mg ${ }^{-1}$ ) (Figure 2C). The decyclization of 3-carene yielded $\alpha$-terpinene (1146 fkat mg ${ }^{-1}$ ), limonene $\left(1162 \mathrm{fkat} \mathrm{mg}^{-1}\right.$ ) and terpinolene (476 fkat $\mathrm{mg}^{-1}$ ) (Figure 2D). The ring-opening of the bicyclic monoterpenes was observed in cell lysates, but not in the soluble or the membrane fraction obtained after separation by ultracentrifugation $(230,000 \times g$ for $40 \mathrm{~min}$ at $4{ }^{\circ} \mathrm{C}$ ). The recombination of the resuspended 75 Svedberg membrane pellet with the 
supernatant did not restore enzyme activity. This suggests an irreversible disruption of an enzyme complex and may be considered in future attempts to purify the enzyme.
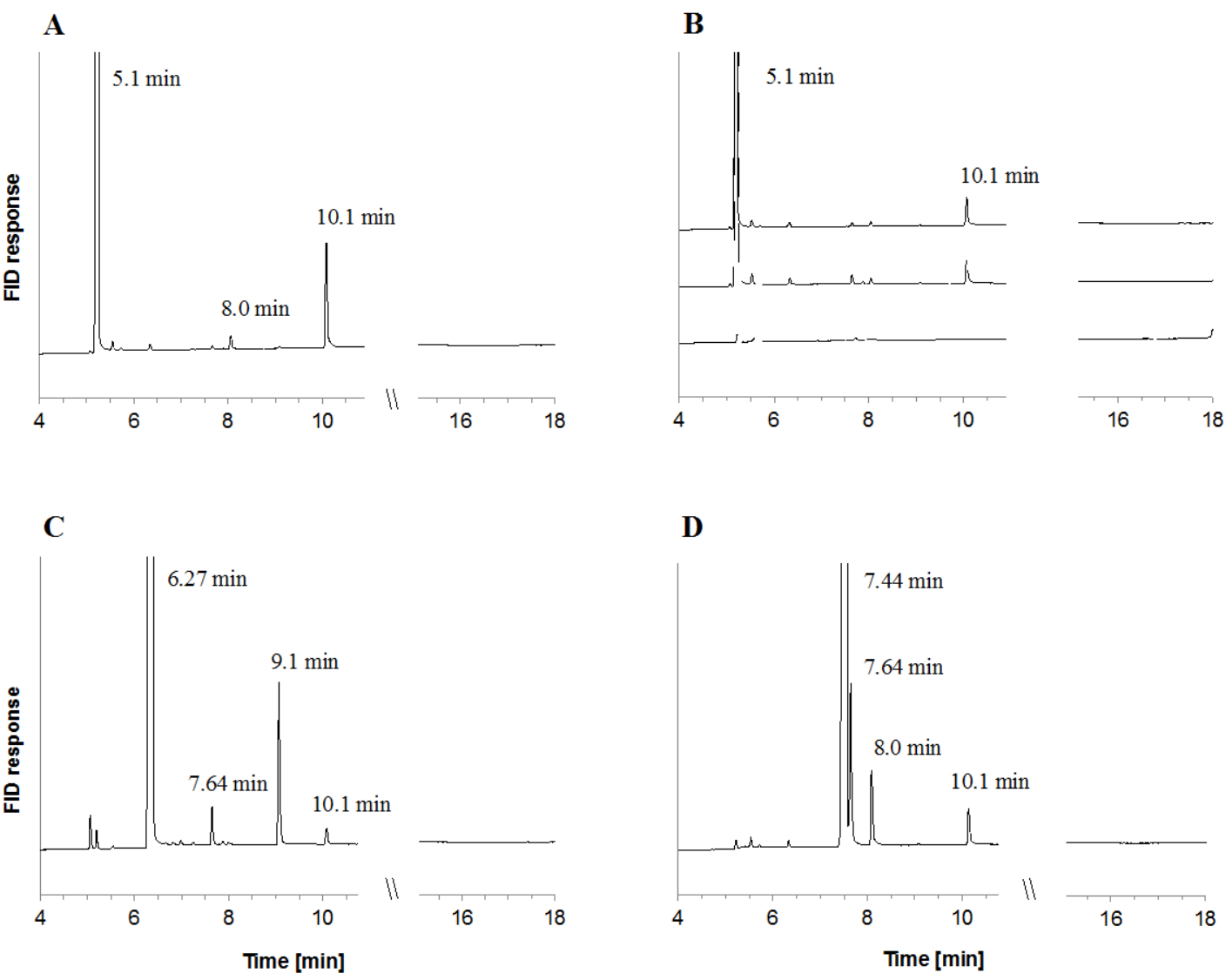

Figure 2. Metabolites formed in vitro from $\alpha$-pinene $(\mathbf{A}, \mathbf{B})$, sabinene $(\mathbf{C})$ and 3-carene $(\mathbf{D})$ by dialyzed cell lysates of pinene-grown $C$. defragrans 65Phen. The $y$-axis has the same scale in all graphs; (B) terpinolene formation from $\alpha$-pinene was hampered after EDTA addition ( $25 \mathrm{mM}$ ) (solid line) or in the absence of divalent cations and ATP (dashed line); the cell lysate did not contain monoterpenes (dotted line). Monoterpenes were identified by GC-MS, standard addition analysis and retention time comparison with authentic standards: $\alpha$-pinene $(5.1 \mathrm{~min})$, sabinene $(6.27 \mathrm{~min}), 3$-carene $(7.44 \mathrm{~min})$ $\alpha$-terpinene (7.64 $\mathrm{min})$, limonene $(8.0 \mathrm{~min}), \gamma$-terpinene $(9.1 \mathrm{~min})$ and terpinolene $(10.1 \mathrm{~min})$.

\subsection{Differential Proteomics}

Growth of wild-type C. defragrans in $\alpha$-phellandrene resulted in the upregulated content of 107 proteins in comparison to the proteome of acetate-grown cells [19]. In this study, we investigated the proteomes of $C$. defragrans 65Phen grown on acetate or on one of the monoterpenes $R-(+)$-limonene, sabinene and $\alpha$-pinene as single carbon source to identify links between the metabolism of bicyclic and monocyclic monoterpenes. Soluble proteins were separated by anion exchange chromatography and one-dimensional denaturing gel electrophoresis and then protein bands were identified by MALDI-ToF-MS. This approach detected 33 proteins with higher concentration in monoterpene-grown cells (Table 2). 
Table 2. Proteins of $C$. defragrans 65Phen present in larger amounts in cells grown on monoterpenes compared to cells grown on acetate. Proteins were fractionated with anion exchange chromatography, semi-quantified by SDS-PAGE (In-gel protein band intensity: +, observable; $(+)$ weakly observable; -, not visible) and identified by MALDI-ToF-MS. Carbon source: L, R-(+)-limonene (monocyclic); $\mathrm{S}$, sabinene (bicyclic); $\mathrm{P}, \alpha$-pinene (bicyclic).

\begin{tabular}{|c|c|c|c|c|}
\hline \multirow{2}{*}{$\begin{array}{c}\text { Accession } \\
\text { Number }\end{array}$} & \multirow{2}{*}{ Annotation } & \multicolumn{3}{|c|}{ Growth Substrate } \\
\hline & & $\mathbf{L}$ & $\mathrm{S}$ & $\mathbf{P}$ \\
\hline CDM22609 & Translation elongation factor $\mathrm{Tu}$ & + & - & - \\
\hline CDM22610 & Translation elongation factor G & + & + & + \\
\hline CDM22641 & Translation elongation factor Tu & + & - & - \\
\hline CDM22907 & Copper-containing nitrite reductase & + & + & + \\
\hline CDM23001 & Aconitate hydratase & + & + & + \\
\hline CDM23572 & Methylmalonate-semialdehyde dehydrogenase & + & + & + \\
\hline CDM23679 & Heat shock protein 60 family chaperone GroEL & + & + & + \\
\hline CDM23795 & Chaperone protein DnaK & + & + & + \\
\hline CDM23915 & 3-methylmercaptopropionyl-CoA dehydrogenase DmdC & + & + & + \\
\hline CDM24415 & Hypothetical protein & + & + & + \\
\hline CDM24550 & Glutamine synthetase type I & + & + & + \\
\hline CDM24733 & Isoleucyl-tRNA synthetase & + & + & + \\
\hline CDM24892 & Membrane alanine aminopeptidase $\mathrm{N}$ & - & + & + \\
\hline CDM24998 & Transcription termination protein NusA & + & - & + \\
\hline CDM25009 & Acetoacetyl-CoA reductase & + & + & + \\
\hline CDM25072 & Citrate synthase & + & + & + \\
\hline CDM25085 & Aconitate hydratase 2 & + & + & + \\
\hline CDM25210 & Polyribonucleotide nucleotidyltransferase & $(+)$ & + & + \\
\hline CDM25241 & Acyl-CoA dehydrogenase & + & + & + \\
\hline CDM25246 & 3-hydroxyacyl-CoA dehydrogenase & $(+)$ & + & + \\
\hline CDM25251 & 4-isopropenyl-2-oxo-cyclohexane-1-carboxyl-CoA hydrolase MrcE & $(+)$ & + & + \\
\hline CDM25253 & 2,4-enoyl-CoA reductase $\mathrm{MrcC}$ & + & + & + \\
\hline CDM25259 & RND efflux transporter component & + & + & + \\
\hline CDM25260 & RND efflux transporter component & + & + & + \\
\hline CDM25267 & Geraniol dehydrogenase GeoA & $(+)$ & + & + \\
\hline CDM25281 & Geranial dehydrogenase GeoB & - & + & + \\
\hline CDM25285 & NADH:ferredoxin oxidoreductase CtmF & + & + & + \\
\hline CDM25289 & Limonene dehydrogenase $\mathrm{CtmB}$ & + & + & + \\
\hline CDM25290 & Limonene dehydrogenase $\mathrm{CtmA}$ & + & + & + \\
\hline CDM25340 & Branched-chain amino acid aminotransferase & - & + & + \\
\hline CDM25770 & Protein export cytoplasm protein SecA & - & - & + \\
\hline CDM25844 & Heat shock protein 60 family chaperone GroEL & + & + & + \\
\hline CDM26013 & Glutamate aspartate periplasmic binding protein precursor GltI & + & + & + \\
\hline
\end{tabular}

Twenty-seven of the identified proteins were present in larger concentrations in all three monoterpene substrates. Among them were several proteins encoded in the genomic island for monoterpene degradation and known to participate in the metabolism of monocyclic monoterpenes. Proteins CtmA, CtmB and CtmF (CDM25290, CDM25289 and CMD25285, respectively) are synthesized from the gene cluster $\operatorname{ctm} A B C D E F G$, known to be responsible for the hydroxylation of limonene to perillyl alcohol $[19,21]$. GeoA (CDM25267) and GeoB (CDM25281) catalyze the oxidation of perillyl alcohol and perillyl aldehyde, respectively, resulting in the formation of perillic acid [20]. These and another eight proteins (CDM23572, CDM24415, CDM25009, CDM25241, CDM25246, CDM25251, CDM25259 and CDM25260) were previously detected as proteins with a higher cellular concentration during growth of $C$. defragrans on the monocyclic monoterpene $\alpha$-phellandrene [19]. These findings link the pathway for bicyclic monoterpene degradation with that for monocyclic monoterpenes. Still, these experiments did not identify a candidate protein responsible for the cycloisomerization of the bicyclic substrates.

\subsection{Transposon Conjugants Affected Growth on Monoterpenes}

To discover the genes involved in bicyclic monoterpene metabolism, random transposon mutagenesis was performed by means of the mini-Tn5 transposon hosted in the vector 
pRL27 [24]. Delivery into C. defragrans 65Phen by biparental conjugation resulted in the generation 8896 transconjugants growing with acetate on solid media. These strains were screened on solid medium replacing acetate by one of the monoterpenes limonene, sabinene, $\alpha$-pinene, or 3-carene supplied via the gas phase. Forty-two of the transconjugants showed impaired growth on at least one of the monoterpenes. Thirty-five unique transposon insertion sites were identified by bidirectional sequencing after rescue cloning (Table 3). The mutation rate of $3.93 \times 10^{-3}$ was in the range previously observed in similar transposon studies $[19,24,25]$. Three transposon insertions occurred within the genetic island for monoterpene degradation affecting proteins CDM25252, CDM25285 and CDM25290 (genes $m r c D, c t m F$ and upstream of $c t m A$, respectively) [19]. Insertions in other genes involved in $\beta$-oxidation-like reactions, amino acid degradation and the methylisocitrate cycle (CDM25923, CDM22783 and CDM25080, respectively) also resulted in low to no bacterial growth on monoterpenes (Table 3).

Four $\mathrm{ABC}$ transporter genes were inactivated in six transconjugants. The corresponding proteins CDM23032 and CDM23105 had been annotated as components of nutrient uptake systems, whereas CDM23018 and CDM24629 were associated to the export of toxins and antibiotics. Inactivated was also a fifth transporter (CDM24678) that affiliated to the superfamily of proton-driven drug/metabolite transporters. Other transposon insertions took place in genes related to miscellaneous amino acid metabolism (CDM22986, CDM24922), cell wall synthesis (CDM24591), water homeostasis (CDM23452, CDM24706) and several other genes, which currently cannot be linked to monoterpene metabolism, but may contribute to the integrity of the cell in the presence of toxic monoterpenes. Remarkably, several transposon insertions occurred in non-coding regions in front of genes. Seven out of 11 of these insertions were more than $250 \mathrm{bp}$ upstream of the start codon. For the remaining four mutants (CDM22986, CDM23110, CDM25290 and CDM25994), the insertion occurred less than 100 bp upstream of the respective transcription start sites, which might have affected gene expression. 
Table 3. Genetic and physiological features of $C$. defragrans 65Phen transconjugants affected in the metabolism of monoterpenes. Growth on monoterpenes was tested on solid and in liquid media. Carbon sources: L, R-(+)-limonene; $\mathrm{S}$, sabinene; $\mathrm{P}, \alpha$-pinene; $\mathrm{C}, 3$-carene. Growth quantification in liquid was based on $\Delta \mathrm{OD} 600$ : $+=\Delta \mathrm{OD}_{600} \geq 0.15 ;(+) \geq 0.05 ;-<0.05$.

\begin{tabular}{|c|c|c|c|c|c|c|c|c|c|c|c|}
\hline \multirow{2}{*}{$\begin{array}{l}\text { Affected Protein } \\
\text { (acc. no.) }\end{array}$} & \multirow{2}{*}{$\begin{array}{c}\text { Gen Length } \\
{[\mathrm{bp}]}\end{array}$} & \multirow{2}{*}{$\begin{array}{c}\text { Insertion } \\
\text { Position [bp] }\end{array}$} & \multirow{2}{*}{ Annotation } & \multicolumn{4}{|c|}{ Growth on Solid Media } & \multicolumn{4}{|c|}{ Growth in Liquid Media } \\
\hline & & & & L & $\mathbf{S}$ & $\mathbf{P}$ & $\mathrm{C}$ & L & $\mathrm{S}$ & $\mathbf{P}$ & $\mathrm{C}$ \\
\hline Wild-Type & - & - & - & + & + & + & + & + & + & + & + \\
\hline CDM22783 & 1217 & 1023 & Cystathionine beta-lyase & - & - & - & - & - & - & - & - \\
\hline CDM23032 & 702 & 793 & Glutamate $\mathrm{ABC}$ transporter permease (periplasmic component) & - & - & - & - & + & - & - & - \\
\hline CDM23105 & 930 & 627 & High-affinity branched-chain amino acid transport system (permease protein) LivH & - & - & - & - & - & - & - & - \\
\hline CDM23105 & 930 & 161 & High-affinity branched-chain amino acid transport system (permease protein) LivH & $(+)$ & $(+)$ & - & - & + & - & - & - \\
\hline CDM23279 & 2793 & 411 & Inositol phosphate phosphatase & $(+)$ & - & - & - & - & $(+)$ & $(+)$ & - \\
\hline CDM23452 & 1230 & 150 & Fused spore maturation proteins $\mathrm{A}$ and $\mathrm{B}$ & $(+)$ & - & - & $(+)$ & $(+)$ & $(+)$ & - & $(+)$ \\
\hline CDM23960 & 1230 & 765 & Glycolate dehydrogenase (iron-sulfur subunit) & - & - & - & - & + & - & - & $(+)$ \\
\hline CDM24063 & 279 & 243 & HigB toxin protein & - & - & - & $(+)$ & $(+)$ & - & - & $(+)$ \\
\hline CDM24591 & 3630 & 889 & $\mathrm{O}$-antigen biosynthesis protein & $(+)$ & - & - & - & $(+)$ & - & - & - \\
\hline CDM24600 & 1029 & 1012 & Glycosyl transferase, family 2 & - & - & - & $(+)$ & + & + & - & - \\
\hline CDM24629 & 1116 & 11 & $\mathrm{ABC}$ transport system (permease component) YbhR & - & - & - & - & - & - & - & $(+)$ \\
\hline CDM24629 & 1116 & 1104 & $\mathrm{ABC}$ transport system (permease component) YbhR & - & - & - & - & - & - & - & - \\
\hline CDM24678 & 897 & 388 & Permease of the drug/metabolite transporter superfamily & - & - & $(+)$ & $(+)$ & - & - & $(+)$ & $(+)$ \\
\hline CDM24706 & 3387 & 2695 & Trehalose synthase & - & - & - & - & - & - & - & - \\
\hline CDM24919 & 3840 & 1904 & Putative ATP-dependent helicase & - & - & - & - & - & - & - & - \\
\hline CDM24922 & 1356 & 1253 & $\mathrm{~N}$-acetylglutamate synthase & - & - & $(+)$ & $(+)$ & $(+)$ & + & - & - \\
\hline CDM25080 & 900 & 88 & Methylisocitrate lyase & $(+)$ & - & - & - & $(+)$ & + & + & - \\
\hline CDM25154 & 525 & 334 & Hypothetical protein & $(+)$ & - & - & - & + & + & - & + \\
\hline CDM25252 & 771 & 497 & 2-hydroxy-4-isopropenyl-cyclohexane-1-carboxyl-CoA dehydrogenase MrcD & $(+)$ & - & - & - & - & - & - & - \\
\hline CDM25285 & 1230 & 492 & NADH:ferredoxin oxidoreductase CtmF & - & - & - & - & - & - & - & - \\
\hline CDM25322 & 999 & 468 & Hypothetical protein & - & $(+)$ & - & - & + & $(+)$ & $(+)$ & - \\
\hline CDM25752 & 849 & 330 & Glucose-1-phosphate thymidylyltransferase & $(+)$ & + & - & - & + & + & - & - \\
\hline CDM25923 & 777 & 223 & Enoyl-CoA hydratase & - & - & - & - & - & - & - & - \\
\hline CDM26084 & 1514 & 1428 & Putative transposase & - & - & - & $(+)$ & $(+)$ & - & $(+)$ & + \\
\hline Non-coding region & - & -500 & Upstream of CDM22657: single-stranded DNA-binding protein & - & - & - & $(+)$ & + & + & $(+)$ & - \\
\hline Non-coding region & - & -10 & Upstream of CDM22986: phenylacetate-CoA ligase & $(+)$ & - & - & - & + & + & - & - \\
\hline Non-coding region & - & 26 & Downstream of CDM23018: auxin efflux transporter & - & - & - & $(+)$ & - & - & - & + \\
\hline Non-coding region & - & -387 & Upstream of CDM23059: hypothetical protein & - & - & - & - & - & - & - & - \\
\hline Non-coding region & - & -97 & Upstream of CDM23110: glutamate ABC transporter (periplasmic component) & - & - & - & - & + & - & - & - \\
\hline Non-coding region & - & -281 & Upstream of CDM23992: hypothetical transcriptional regulator & - & $(+)$ & - & - & $(+)$ & $(+)$ & - & - \\
\hline Non-coding region & - & -559 & Upstream of CDM23992: putative transposase & $(+)$ & - & - & $(+)$ & + & - & - & - \\
\hline Non-coding region & - & -270 & Upstream of CDM23993: putative transcriptional regulator & $(+)$ & - & - & - & + & + & - & - \\
\hline Non-coding region & - & -78 & Usptream of CDM25290: limonene dehydrogenase CtmA & $(+)$ & $(+)$ & $(+)$ & - & - & $(+)$ & - & - \\
\hline Non-coding region & - & -40 & Upstream of CDM25994: thiamin-phosphate pyrophosphatase & - & - & - & - & - & - & - & - \\
\hline Non-coding region & - & -295 & Upstream of CDM26087: putative transposase & $(+)$ & - & - & - & + & - & - & - \\
\hline
\end{tabular}




\section{Discussion}

In the past, traces of $\alpha$-terpinene, cymene and limonene $(4-20 \mu \mathrm{M})$ were observed in cultures of $C$. defragrans grown with bicyclic monoterpenes [13]. Here, we elevated the concentrations of intermediate metabolites using a mutant strain unable to mineralize monocyclic monoterpenes and a cometabolic metabolism with acetate as growth substrate. The mutant strain formed larger amounts than the wild type strain, but the pattern of the monoterpene metabolites remained stable. We observed the formation and accumulation of several monocyclic monoterpenes $(18-368 \mu \mathrm{M})$, which all support as individual substance growth of $C$. defragrans [15]. These observations indicate that the traces of monoterpenes found in wild-type cultures indeed are not accidental side-products, but true intermediates of the degradation pathways.

The isomerization of the bicyclic substrates into monocyclic monoterpenes requires the opening of the cyclopropyl ring present in carene and sabinene as well as the cyclobutyl ring in pinene. This process is expected to involve a transient carbocation intermediate [26,27]. In 1968, Shukla and Bhattacharyya proposed a carbocation as precursor for all monocyclic products of an aerobic Pseudomonas strain metabolizing $\alpha$-and $\beta$-pinene [28], a hypothesis that has since gained additional evidence $[26,29,30]$. The products detected in $C$. defragrans suggest the transient formation of terpinen-4-yl and $\alpha$-terpinyl carbocations, yielding either monocyclic olefins via deprotonation (limonene, terpinolene) or monoterpene alcohols via combination with hydroxide ions or water. The stimulating role of divalent cations and ATP in the synthesis of unsubtituted monocyclic monoterpenes is an aim for future research, but may involve enzyme modifications or the dehydroxylation of these alcohol intermediates via phosphorylation and elimination of phosphate or pyrophosphate (Figure 3).

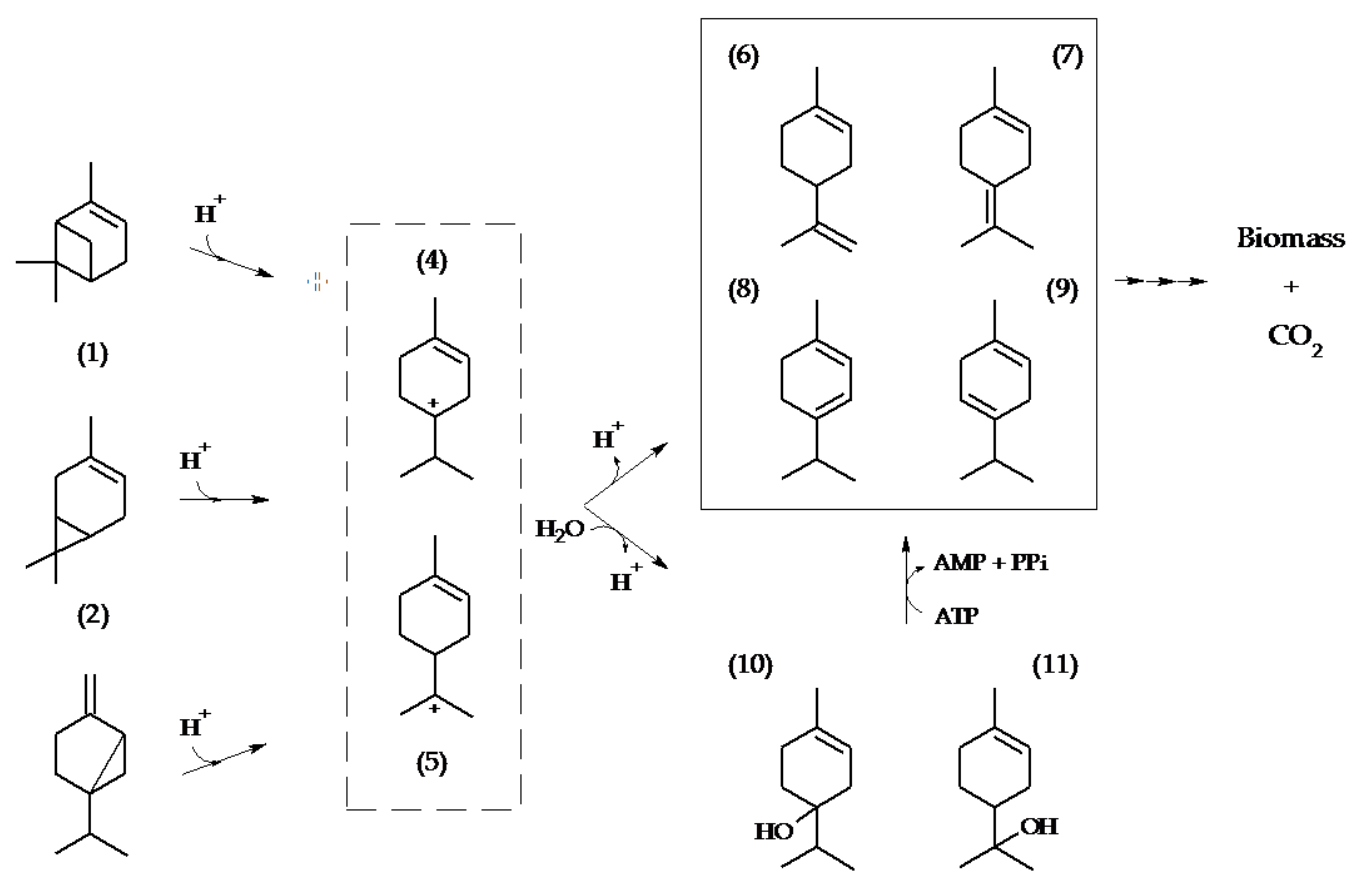

(3)

Figure 3. Proposed pathway for the degradation of the bicyclic monoterpenes $\alpha$-pinene (1), 3-carene (2) and sabinene (3) in C. defragrans 65Phen. Electrophilic attack on the allylic double bond and an intramolecular rearrangement generates the monocyclic transient carbocations terpinen-4-yl (4) and $\alpha$-terpinyl (5). These can deprotonate into monocyclic monoterpene olefins such as (6), (7), (8), (9) or hydroxylated to (10) and (11) by water addition. The alcohols may be dehydrated via an ATP-dependent reaction to monoterpene olefins. 
The detection of several proteins involved in monocyclic monoterpene degradation provided additional indirect evidence for the mineralization of bicyclic monoterpenes via monocyclic intermediates. In addition, insertion mutations affecting growth on bicyclic monoterpenes were identified in genes (or upstream of genes) required for the mineralization of monocyclic monoterpenes. Transposon mutants were also affected in genes predicted to be part of defense or detoxification mechanisms such as outer membrane components or membrane permeases, linking the phenotypes to the toxicity of monoterpenes [19,25]. In summary, our observations suggest an isomerization of bicyclic monoterpenes into monocyclic intermediates, prior to their complete mineralization via the monocyclic monoterpene pathway [19]. These decyclization reactions were stimulated by divalent ions and ATP, but a detailed understanding has to await the isolation of the enzyme. So far, the involvement of $\alpha$-terpinyl and terpinen-4-yl carbocations does best explain the formation of monocyclic monoterpenes.

\section{Methods}

\subsection{Bacterial Cells}

The strains and plasmids used in this study are listed in Table 4.

Table 4. List of bacterial strains used in this study.

\begin{tabular}{lcc}
\hline Strain & Genotype & Source \\
\hline C. defragrans 65Phen & Rifampicin-resistant $\left(\mathrm{Ra}^{\mathrm{R}}\right)$ & [31] \\
\hline C. defragrans 65Phen $\triangle c t m A B$ & 65Phen, $\mathrm{Ra}^{\mathrm{R}}, \Delta c t m A B$ & This work \\
\hline E. coli BW20767 & $\begin{array}{r}\text { RP4-2-tet::Mu-1, kan::Tn7 integrant, leu-63::IS10, recA1, } \\
\text { creC510, hsdR17, endA1, zbf-5, uidA, }(\Delta M l u l):: \text { pir }{ }^{+} \text {thi }\end{array}$ & [32] \\
\hline Plasmid & & \\
\hline pRL27 & Tn5 with $\mathrm{Km}^{\mathrm{R}}, \mathrm{R} 6 \mathrm{~K}$ ori, oriT, RP4, tnpA & [24] \\
\hline
\end{tabular}

The in-frame deletion mutant $\triangle c t m A B$ was prepared as described elsewhere [31] and kindly provided by Jan Petasch (Max Planck Institute for Marine Microbiology, Bremen, Germany).

\subsection{Culture Conditions}

Liquid cultures of Castellaniella defragrans 65Phen and all mutants thereof grew under anoxic denitrifying conditions in Artificial Fresh Water (AFW) medium as described [19]. Unless otherwise indicated, $20 \mathrm{mM}$ of sodium acetate or $3 \mathrm{mM}$ of monoterpene was provided as carbon sources. Monoterpenes were supplied in liquid cultures by means of the carrier phase 2,2,4,4,6,8,8-heptamethylnonane (HMN). Cultures were incubated at $28^{\circ} \mathrm{C}$ under constant shaking (60 rpm). E. coli BW20767 was grown at $37^{\circ} \mathrm{C}$ under constant shaking (140 rpm) in Luria Bertani (LB) broth. The plasmid pRL27 was maintained in cultures containing $25 \mu \mathrm{g} \mathrm{mL}{ }^{-1}$ of kanamycin.

\subsection{Metabolite Analysis}

C. defragrans strains 65Phen and $\triangle c t m A B$ were inoculated in $10 \mathrm{ml}$ liquid AFW medium containing $20 \mathrm{mM}$ acetate and $3 \mathrm{mM}$ of sabinene, 3-carene or $\alpha$-pinene. The monoterpenes were dissolved in a filter-sterilized $10 \% v / v$ Tween 20 solution. Tween 20 was not a growth substrate and had a final concentration of $0.5 \% v / v$ in the medium. After 7 days of culture growth, the metabolites were salted out from the aqueous phase by addition of $500 \mu \mathrm{L}$ of isopropanol, followed by the addition of $5 \mathrm{~g}$ of $\mathrm{K}_{2} \mathrm{CO}_{3}$. The suspension was homogenized for $20 \mathrm{~min}$ at $60 \mathrm{rpm}$ for and then stood vertically $10 \mathrm{~min}$ for phase separation. One $\mu \mathrm{L}$ of the upper (organic) phase was analyzed in a gas chromatograph (Perkin Elmer Auto System XL, Überlingen, Germany) equipped with an Optima ${ }^{\circledR}-5$ column $(0.25-\mu m$ film thickness, $50 \mathrm{~m} \times$ 0.32-mm inner diameter; Macherey-Nagel, Düren, Germany) and coupled to a flame ionization detector (FID). The temperature program was: injection port $250{ }^{\circ} \mathrm{C}$; column 
for $2 \mathrm{~min}$ at $40^{\circ} \mathrm{C}$, increate at a rate of $4{ }^{\circ} \mathrm{C} \mathrm{min}-1$ until $100{ }^{\circ} \mathrm{C}$, constant for $0.1 \mathrm{~min}$, at a rate of $45^{\circ} \mathrm{C} \mathrm{min}{ }^{-1}$ up to $320{ }^{\circ} \mathrm{C}$, and constant at $320{ }^{\circ} \mathrm{C}$ for $3 \mathrm{~min}$; detection temperature $350{ }^{\circ} \mathrm{C}$. The split ratio was 1:9. FID responses for $\mathrm{R}-(+)$-limonene, $\alpha$ - and $\gamma$-terpinene, terpinolene and $\alpha$-terpineol were $5.26 \pm 0.24 \mathrm{mV}^{*}$ s per picomol carbon. For terpinen-4-ol, the response was $4.1 \mathrm{mV}^{*} \mathrm{~s}$ per picomol carbon. Calibration curves for monoterpene dienes were linear within the range of $0.1-10 \mathrm{nmol}$ of injected monoterpene. For terpinen-4-ol and $\alpha$-terpineol, linearity ranged between 0.5 and $10 \mathrm{nmol}$. In all cases, the coefficient of determination $\left(\mathrm{R}^{2}\right)$ was higher than 0.99 . Monoterpene concentrations refer to their theoretical concentrations in the aqueous phase. Metabolite identity initially defined by retention time was confirmed by GC-MS analysis on an Agilent 7890B gas chromatograph (Agilent, Santa Clara, CA, USA) connected to an Agilent 5977A Mass-selective detector. Analyte separation was performed on an Agilent $30 \mathrm{~m}$ DB5-MS column with a $10 \mathrm{~m}$ DuraGuard column applying the following temperature program: injection port temperature at $250{ }^{\circ} \mathrm{C}$, initial column temperature $40{ }^{\circ} \mathrm{C}$ for $1 \mathrm{~min}$, increasing to $160{ }^{\circ} \mathrm{C}$ at $4^{\circ} \mathrm{C} \mathrm{min}-1$ further to $280{ }^{\circ} \mathrm{C}$ at $30{ }^{\circ} \mathrm{C} \mathrm{min}-1$ and hold for $1 \mathrm{~min}$. For verification, mass spectra of monoterpene standards were recorded as reference. Metabolites were then identified by their mass spectra.

\subsection{Enzyme Assays}

All activity experiments were performed in the absence of oxygen. Cells of wild-type C. defragrans grown anaerobically on $\alpha$-pinene were resuspended in $25 \mathrm{mM}$ Tris- $\mathrm{Cl}, \mathrm{pH} 8.0$ and disrupted by two passages through a French-Press cell disrupter (SLM Aminco, Rochester, NY, USA) at 8.6 MPa. The crude cell lysate, as well as the soluble and pelleted fractions obtained after ultracentrifugation $\left(230,000 \times g\right.$ for $30 \mathrm{~min}$ at $\left.4^{\circ} \mathrm{C}\right)$, were dialyzed in anoxic $25 \mathrm{mM}$ Tris-Cl, pH $8.0\left(1: 10^{6}\right)$ and tested for enzyme activity. A $500 \mu \mathrm{L}$ assay contained $2.5-5 \mathrm{mg}$ protein, $2 \mathrm{mM}$ dithiothreitol, $5 \mathrm{mM} \mathrm{Mg}^{2+}$, $10 \mathrm{mM} \mathrm{Mn}{ }^{2+}, 10 \mathrm{mM}$ ATP, 0.5\% Tween 20 and $60 \mathrm{mM}$ of a bicyclic monoterpene. When indicated, divalent cations were replaced for $10 \mathrm{mM} \mathrm{Ca}^{2+}$ supplied as $\mathrm{CaCl}_{2}$. The reactions were initiated by monoterpene addition and incubated for $16-18 \mathrm{~h}$ at $28^{\circ} \mathrm{C}$. Hydrophobic metabolites were extracted with $100 \mu \mathrm{L} n$-hexane and analyzed by GC-FID as aforementioned. Retention times shown in Figures 1 and 2 are shifted due to column shortening during equipment maintenance. Monoterpene identity was confirmed by analysis with internal standards and GC-MS analysis.

\subsection{Differential Proteomics: Preparation of Cell Lysates, Soluble Protein Fractionation and MALDI-ToF Analysis}

Cells of $C$. defragrans were cultivated in $10 \mathrm{~mL}$ of AFW medium supplemented with either $20 \mathrm{mM}$ acetate or $3 \mathrm{mM}$ of R-(+)-limonene, 3-carene, sabinene or $\alpha$-pinene and sodium nitrate $(10 \mathrm{mM})$. Growth was determined as increase in optical density at $600 \mathrm{~nm}$. Transfers to fresh medium were carried out once a week with an inoculum of $2 \%$ vol/vol. After at least 5 consecutive transfers, $5 \mathrm{~mL}$ of 5 to 7 days-grown cultures were transferred into $2000 \mathrm{~mL}$ of fresh AFW. At this scale, nitrate concentration was increased to $20 \mathrm{mM}$ and the monoterpenes were added without a carrier phase. The biomass was harvested at late exponential phase and resuspended in $10 \mathrm{mM}$ potassium phosphate, $\mathrm{pH}$ 8.0. After cell disruption, soluble proteins were separated from cell debris by ultracentrifugation at $230,000 \times g$ for $40 \mathrm{~min}$ at $4{ }^{\circ} \mathrm{C}$. Protein concentration was determined by the method of Bradford [33] with bovine serum albumin as the standard. 20 to $40 \mathrm{mg}$ of the soluble proteins were loaded onto a Resource ${ }^{\mathrm{TM}} \mathrm{Q}$ column (GE Healthcare, Freiburg, Germany) with a $1 \mathrm{~mL}$ bed volume installed in an ÄKTA purifier system (GE Healthcare, Freiburg, Germany) that was equilibrated with $10 \mathrm{mM}$ potassium phosphate, $\mathrm{pH}$ 8.0. Protein fractionation was performed by applying a salinity gradient from 0-500 mM KCl over 50 nominal column volumes (flow rate: $0.5 \mathrm{~mL} \mathrm{~min}{ }^{-1}$ ) with a collection in 25 fractions of $2 \mathrm{~mL}$. Unbound proteins (flow-through) were collected as a single additional fraction. Each fraction was separated by size and stained in one-dimensional SDS-PAGE as described by Laemmli [34]. A comparison identified proteins present in different amounts. These were excised, subjected to tryptic in-gel digestion and analyzed on an AB SCIEX TOF/TOF ${ }^{\mathrm{TM}} 5800$ Analyzer (AB Sciex, Darmstadt, Germany). 


\subsection{Transposon Mutagenesis}

The generation of transposon insertion mutants and the evaluation of their ability to grow on monoterpenes proceeded as described by Petasch et al. [19]. Mutants with low to no growth on limonene, 3-carene, sabinene and/or $\alpha$-pinene were selected for further examination. The genomic localization of the Tn 5 mini-transposon in each mutant was determined by sequencing after rescue cloning. DNA was extracted from mutant cells from over-night cultures grown in LB medium [35]. One $\mu \mathrm{g}$ of genomic DNA was digested with BamHI (Thermo Fisher Scientific, Waltham, MA, USA) and purified with the GeneJET PCR Purification Kit (Thermo Fisher Scientific). The BamHI fragments were circularized with T4 DNA ligase (Thermo Fisher Scientific). The circularized DNA fragments were transformed into chemically competent E. coli BW20767 $\left(\right.$ pir $\left.^{+}\right)$. Clones with the ability to grow on kanamycin-containing LB medium were selected and plasmids were extracted (QIAprep Spin Miniprep Kit, QIAGEN, Hilden, Germany). Sequencing reactions were prepared with 100 to $200 \mathrm{ng}$ of plasmid DNA and the BigDye Terminator v3.1 Cycle Sequencing Kit (Applied Biosystems, Life Technologies Corporation, Carlsbad, CA, USA). The oligonucleotides tpnRL17-1 (AACAAGCCAGGGATGTAA) and tpnRL 13-2 (CAGCAACACCTTCTTCACGA) were used to prime the reactions [24]. The temperature program used was $96{ }^{\circ} \mathrm{C}$ for $5 \mathrm{~min}, 99$ cycles of $96{ }^{\circ} \mathrm{C}$ for $20 \mathrm{~s}, 55^{\circ} \mathrm{C}$ for $10 \mathrm{~s}$ and $60{ }^{\circ} \mathrm{C}$ for $5 \mathrm{~min}$. The DNA sequences were read on an ABI Prism 3130xl Genetic Analyzer (Applied Biosystems Life Technologies Corporation, Carlsbad, CA, USA).

Acknowledgments: We thank Jan Petasch for generously supplying us with the strain $C$. defragrans 65Phen $\triangle c t m A B$. E.P.C. was funded by the Colombian national education ministry, the Corporación para la Investigación de la Corrosión (Colombia) and the German academic exchange service (DAAD). The project was financed by the Max Plank Society.

Author Contributions: Edinson Puentes-Cala and Jens Harder conceived and designed the experiments; Edinson Puentes-Cala performed the experiments; Edinson Puentes-Cala and Manuel Liebeke performed hydrocarbon GC-MS; Stephanie Markert performed MALDI-ToF of protein bands; Edinson Puentes-Cala and Jens Harder analyzed the data and wrote the manuscript.

Conflicts of Interest: The authors declare no conflict of interest.

\section{References}

1. Kesselmeier, J.; Staudt, M. Biogenic volatile organic compounds (VOC): An overview on emission, physiology and ecology. J. Atmos. Chem. 1999, 33, 23-88. [CrossRef]

2. Sharkey, T.D.; Wiberley, A.E.; Donohue, A.R. Isoprene emission from plants: Why and how. Ann. Bot. 2008, 101, 5-18. [CrossRef] [PubMed]

3. Chizzola, R. Regular monoterpenes and sesquiterpenes (essential oils). In Natural Products: Phytochemistry, Botany and Metabolism of Alkaloids, Phenolics and Terpenes; Ramawat, K.G., Mérillon, J.-M., Eds.; Springer: Berlin/Heidelberg, Germany, 2013; pp. 2973-3008.

4. Lathiere, J.; Hauglustaine, D.A.; Friend, A.D.; De Noblet-Ducoudre, N.; Viovy, N.; Folberth, G.A. Impact of climate variability and land use changes on global biogenic volatile organic compound emissions. Atmos. Chem. Phys. 2006, 6, 2129-2146. [CrossRef]

5. Laothawornkitkul, J.; Taylor, J.E.; Paul, N.D.; Hewitt, C.N. Biogenic volatile organic compounds in the earth system. New Phytol. 2009, 183, 27-51. [CrossRef] [PubMed]

6. Guenther, A.B.; Jiang, X.; Heald, C.L.; Sakulyanontvittaya, T.; Duhl, T.; Emmons, L.K.; Wang, X. The Model of Emissions of Gases and Aerosols from Nature version 2.1 (MEGAN2.1): An extended and updated framework for modeling biogenic emissions. Geosci. Model. Dev. 2012, 5, 1471-1492. [CrossRef]

7. Muller, J.F.; Stavrakou, T.; Wallens, S.; De Smedt, I.; Van Roozendael, M.; Potosnak, M.J.; Rinne, J.; Munger, B.; Goldstein, A.; Guenther, A.B. Global isoprene emissions estimated using MEGAN, ECMWF analyses and a detailed canopy environment model. Atmos. Chem. Phys. 2008, 8, 1329-1341. [CrossRef]

8. Hayward, S.; Muncey, R.J.; James, A.E.; Halsall, C.J.; Hewitt, C.N. Monoterpene emissions from soil in a sitka spruce forest. Atmos. Environ. 2001, 35, 4081-4087. [CrossRef] 
9. Owen, S.M.; Clark, S.; Pompe, M.; Semple, K.T. Biogenic volatile organic compounds as potential carbon sources for microbial communities in soil from the rhizosphere of Populus tremula. FEMS Microbiol. Lett. 2007, 268, 34-39. [CrossRef] [PubMed]

10. Seubert, W. Degradation of isoprenoid compounds by micro-organisms. I. Isolation and characterization of an isoprenoid-degrading bacterium, Pseudomonas citronellolis n. sp. J. Bacteriol. 1960, 79, 426-434. [PubMed]

11. Cantwell, S.G.; Lau, E.P.; Watt, D.S.; Fall, R.R. Biodegradation of acyclic isoprenoids by Pseudomonas species. J. Bacteriol. 1978, 135, 324-433. [PubMed]

12. Förster-Fromme, K.; Jendrossek, D. Catabolism of citronellol and related acyclic terpenoids in pseudomonads. Appl. Microbiol. Biotechnol. 2010, 87, 859-869. [CrossRef] [PubMed]

13. Harder, J.; Probian, C. Microbial degradation of monoterpenes in the absence of molecular oxygen. Appl. Environ. Microbiol. 1995, 61, 3804-3808. [PubMed]

14. Foss, S.; Harder, J. Thauera linaloolentis sp. nov. and Thauera terpenica sp. nov., isolated on oxygen-containing monoterpenes (linalool, menthol, and eucalyptol) and nitrate. Syst. Appl. Microbiol. 1998, 21, 365-373. [CrossRef]

15. Foss, S.; Heyen, U.; Harder, J. Alcaligenes defragrans sp. nov., description of four strains isolated on alkenoic monoterpenes ((+)-menthene, alpha-pinene, 2-carene, and alpha-phellandrene) and nitrate. Syst. Appl. Microbiol. 1998, 21, 237-244. [CrossRef]

16. Kämpfer, P.; Denger, K.; Cook, A.M.; Lee, S.T.; Jackel, U.; Denner, E.B.M.; Busse, H.J. Castellaniella gen. nov., to accommodate the phylogenetic lineage of Alcaligenes defragrans, and proposal of Castellaniella defragrans gen. nov., comb. nov and Castellaniella denitrificans sp. nov. Int. J. Syst. Evol. Micr. 2006, 56, 815-819. [CrossRef] [PubMed]

17. Marmulla, R.; Harder, J. Microbial monoterpene transformations-A review. Front. Microbiol. 2014, 5. [CrossRef] [PubMed]

18. Brodkorb, D.; Gottschall, M.; Marmulla, R.; Lüddeke, F.; Harder, J. Linalool dehydratase-isomerase, a bifunctional enzyme in the anaerobic degradation of monoterpenes. J. Biol. Chem. 2010, 285, 30436-30442. [CrossRef] [PubMed]

19. Petasch, J.; Disch, E.M.; Markert, S.; Becher, D.; Schweder, T.; Hüttel, B.; Reinhardt, R.; Harder, J. The oxygenindependent metabolism of cyclic monoterpenes in Castellaniella defragrans 65Phen. BMC Microbiol. 2014, 14, 164. [CrossRef] [PubMed]

20. Lüddeke, F.; Wulfing, A.; Timke, M.; Germer, F.; Weber, J.; Dikfidan, A.; Rahnfeld, T.; Linder, D.; Meyerdierks, A.; Harder, J. Geraniol and geranial dehydrogenases induced in anaerobic monoterpene degradation by Castellaniella defragrans. Appl. Environ. Microbiol. 2012, 78, 2128-2136. [CrossRef] [PubMed]

21. Harder, J.; Marmulla, R. Catabolic pathways and enzymes involved in the anaerobic degradation of terpenes. In Anaerobic Utilization of Hydrocarbons, Oils, and Lipids; Boll, M., Ed.; Springer International Publishing: Cham, Switzerland, 2017; pp. 1-15. [CrossRef]

22. Weidenweber, S.; Marmulla, R.; Ermler, U.; Harder, J. X-ray structure of linalool dehydratase/isomerase from Castellaniella defragrans reveals enzymatic alkene synthesis. FEBS Lett. 2016, 590, 1375-1383. [CrossRef] [PubMed]

23. Lüddeke, F.; Harder, J. Enantiospecific (S)-(+)-linalool formation from beta-myrcene by linalool dehydrataseisomerase. Z. Naturfr. C 2011, 66, 409-412. [CrossRef]

24. Larsen, R.A.; Wilson, M.M.; Guss, A.M.; Metcalf, W.W. Genetic analysis of pigment biosynthesis in Xanthobacter autotrophicus Py2 using a new, highly efficient transposon mutagenesis system that is functional in a wide variety of bacteria. Arch. Microbiol. 2002, 178, 193-201. [CrossRef] [PubMed]

25. Marmulla, R.; Cala, E.P.; Markert, S.; Schweder, T.; Harder, J. The anaerobic linalool metabolism in Thauera linaloolentis 47Lol. BMC Microbiol. 2016, 16, 76. [CrossRef] [PubMed]

26. Yoo, S.K.; Day, D.F. Bacterial metabolism of $\alpha$ - and $\beta$-pinene and related monoterpenes by Pseudomonas sp. strain PIN. Process. Biochem. 2002, 37, 739-745. [CrossRef]

27. Traas, P.C. Advances in the chemistry of some interesting cyclic monoterpene alcohols. In Fragrance Chemistry: The Science of the Sense of Smell; Heimer, E.T., Ed.; Academic Press: San Diego, CA, USA, 1982; pp. 165-219.

28. Shukal, O.P.; Bhattacharyya, P.K. Microbiological transformations of terpenes: Part XI-Pathways of degradation of $\alpha$-\& $\beta$-pinenes in a soil pseudomonad (PL-strain). Indian J. Biochem. 1968, 5, 92-101. 
29. Cheng, Z.W.; Sun, P.F.; Jiang, Y.F.; Zhang, L.L.; Chen, J.M. Kinetic analysis and bacterium metabolization of alpha-pinene by a novel identified Pseudomonas sp. strain. J. Environ. Sci. (China) 2012, 24, 1806-1815. [CrossRef]

30. Narushima, H.; Omori, T.; Minoda, Y. Microbial transformation of alpha-pinene. Eur. J. Appl. Microbiol. 1982, 16, 174-178. [CrossRef]

31. Lüddeke, F.; Dikfidan, A.; Harder, J. Physiology of deletion mutants in the anaerobic beta-myrcene degradation pathway in Castellaniella defragrans. BMC Microbiol. 2012, 12, 192. [CrossRef] [PubMed]

32. Metcalf, W.W.; Jiang, W.; Daniels, L.L.; Kim, S.K.; Haldimann, A.; Wanner, B.L. Conditionally replicative and conjugative plasmids carrying lacZ $\alpha$ for cloning, mutagenesis, and allele replacement in bacteria. Plasmid 1996, 35, 1-13. [CrossRef] [PubMed]

33. Bradford, M.M. A rapid and sensitive method for the quantitation of microgram quantities of protein utilizing the principle of protein-dye binding. Anal. Biochem. 1976, 72, 248-254. [CrossRef]

34. Laemmli, U.K. Cleavage of structural proteins during the assembly of the head of bacteriophage T4. Nature 1970, 227, 680-685. [CrossRef] [PubMed]

35. Martin-Platero, A.M.; Valdivia, E.; Maqueda, M.; Martinez-Bueno, M. Fast, convenient, and economical method for isolating genomic DNA from lactic acid bacteria using a modification of the protein "salting-out" procedure. Anal. Biochem. 2007, 366, 102-104. [CrossRef] [PubMed]

(C) 2018 by the authors. Licensee MDPI, Basel, Switzerland. This article is an open access article distributed under the terms and conditions of the Creative Commons Attribution (CC BY) license (http://creativecommons.org/licenses/by/4.0/). 